\title{
A epopeia do "bem-nascido": Padre Ibiapina e o mito das bem aventuranças
}

\section{Diógenes Faustino do Nascimento ${ }^{1}$, Carlos André Macêdo Cavalcanti $^{2}$ e Joselma Bianca Silva de Souza Mendonça ${ }^{1}$}

\author{
${ }^{1}$ Universidade Federal da Paraíba. Centro de Educação. Programa de \\ Pós-Graduação em Ciências das Religiões. Campus I. João Pessoa-PB, Brasil \\ (CEP 58051-900). E-mail: diogenesnascimento@hotmail.com. \\ ${ }^{2}$ Universidade Federal da Paraíba. Centro de Ciências Humanas Letras e Artes. \\ Departamento de História. Campus I. João Pessoa-PB, Brasil (CEP 58051-900).
}

Resumo. O desenvolvimento do corpo do artigo inicia-se com uma brevíssima contextualização histórica e biográfica da vida e obras do Missionário no nordeste brasileiro. Foram feitos alguns recortes de paisagens textuais destacadas por seus editores e biógrafo apresentando-o como o "escolhido", o "predestinado", o "bem-nascido". Tendo feito tais comentários, foram feitos os destaques, a saber, as passagens textuais do relato da morte do Padre Ibiapina em Arara, hoje Santuário de Santa Fé, no Estado da Paraíba, Nordeste do Brasil. E para tanto fez-se uso da metodologia etnográfica por meio da análise bibliográfica e biográfica ao passo que demonstrou-se a forma simples da passagem do mito para a História, suas significações e releituras. Ao fim e ao cabo, ensejou-se dissertar nas considerações finais como esse contágio mítico, de caráter arcaico, é revivido e rememorado e atualizado em forma relativa de releitura do(s) mito(s).

Palavras-chave: Mito; Padre Ibiapina; Etnografia; Memória.

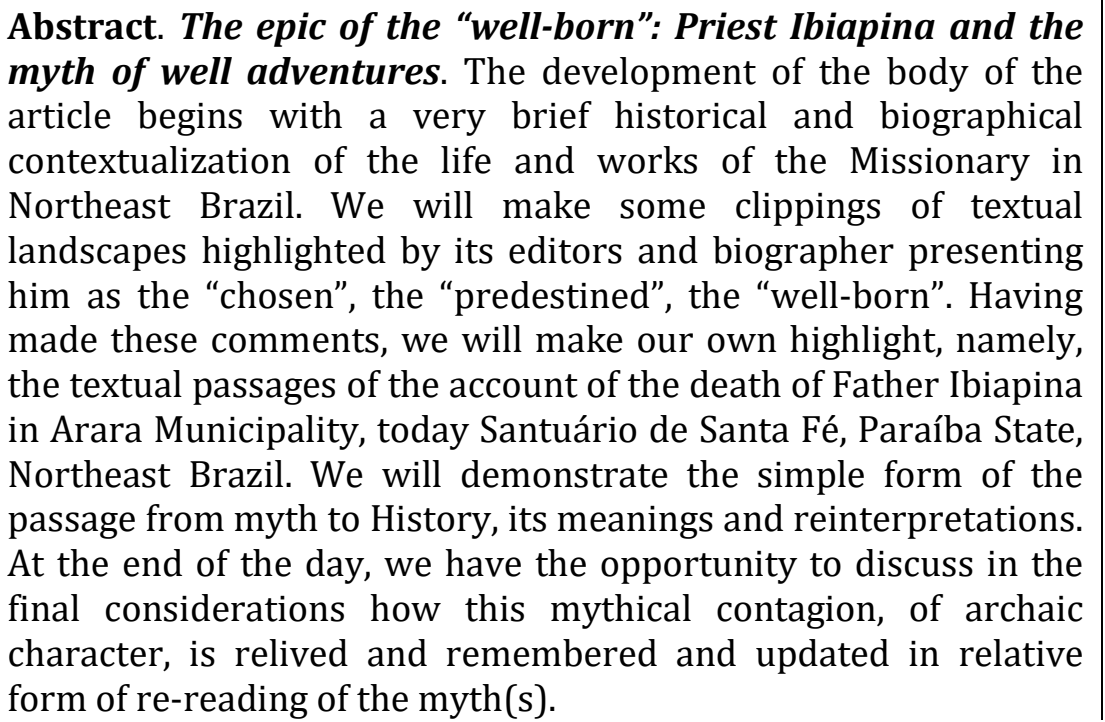

Recebido $04 / 10 / 2020$

Aceito $30 / 12 / 2020$

Publicado

$31 / 12 / 2020$

Acesso aberto

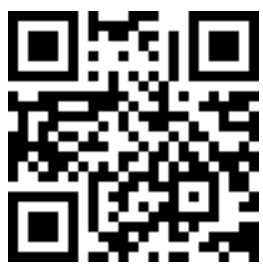

ORCID

(1) 0000-0001-7677-2267 Diógenes Faustino do Nascimento

D) 0000-0003-0685-5803 Carlos André Macêdo Cavalcanti

D) 0000-0003-4785-0830 Joselma Bianca Silva de Souza Mendonça

ISSN 2359-1412/RBGAS-2020-0152/2020/7/17/42/1701

Rev. Bras. Gest. Amb. Sustent.

http://revista.ecogestaobrasil.net 
Keywords: Myth; Father Ibiapina; Ethnography; Memory.

\section{Introdução}

Há 136 anos do seu falecimento ainda se fala do Padre Ibiapina. Que fez esse homem de tão relevante para ser lembrado, celebrado e rememorado por tanto tempo por milhares de pessoas? Mariz (1997, p. 189), em suas considerações sobre esse personagem histórico, revela que o "[...] Ceará perdeu um de seus distintos filhos e o país um homem assaz notável", foi assim que a imprensa paraibana, especificamente o jornal Liberal Paraibano se despedia do Padre Ibiapina".

Com uma imagem de quem por muito tempo permanece nas narrativas de moradores locais e, sobretudo, na devoção popular, o Padre Ibiapina se tornou ícone da religiosidade, ao arrebanhar fieis, com suas promessas, na certeza de serem agraciados pelas mãos que julgavam protetoras. A memória sobre o padre perpassa o campo da religiosidade e desemboca no território acadêmico. Despertando curiosos e pesquisadores a se debruçarem sobre o assunto. Várias obras editoriais, dissertações, artigos, textos e resenhas versam sobre a vida e as obras do Padre José Antônio de Maria Ibiapina. Numa busca na rede mundial de computadores (World Wide Web) o resultado ultrapassa a marca dos 270 mil verbetes. Se a busca for direcionada ao modo de arquivo serão encontrados mais de 51.200 mil referências às publicações, documentários, citações diretas e indiretas para logradouros, prédios públicos etc. Já no formato pdf foram encontrados 1.570 citações, donde se depreende que sua influência vai além dos portões das Universidades do Nordeste, sendo citado como temática acadêmica em quase todas as regiões do Brasil.

Padre Ibiapina atuou no nordeste do país entre 1856 e 1886 construindo hospitais, açudes, casas de caridade, cemitérios e igrejas promovendo a dignidade e a valorização das experiências humanas nas províncias da Paraíba, Rio Grande do Norte, Pernambuco, Ceará e Alagoas. Exerceu o sacerdócio aos 47 anos depois de tantas frustrações com a carreira política e jurídica além de presenciar tantas injustiças sociais. Foi professor de eloquência sagrada, História Sagrada e reitor no Seminário de Olinda em 1854, durante seu primeiro ano de sacerdócio.

Aos 70 anos, uma paralisia afastava o Padre Ibiapina das suas obras e de celebrar missa. Faleceu no dia 19 de fevereiro de 1883, aos 77 anos, na Casa de Santa Fé, em Arara, na Paraíba, dos quais 30 foram dedicados ao povo nordestino. E, desde então, sua vida e obra se tornaram objetos de pesquisa em Universidades e de mitificação pelo povo nordestino que visita o Santuário em Santa Fé e nos diversos locais de peregrinação. Trata-se de uma realidade perene na vida daqueles que durante as caminhadas religiosas, almejam ser contemplados pela presença do santo. Essas prerrogativas trazem a ideia de que a devoção popular injeta na vida dos indivíduos, servindo como mola propulsora em tempos difíceis, pois abrem perspectivas e esperanças futuras. É nesse campo fértil que o mito encontra o seu legado, servindo como força viva para a renovação de inúmeras tradições na história humana (Mendonça, 2014).

\section{Uma perspectiva etnográfica: "quando o mito torna-se História"}

O intuito primeiro compraz-se em demonstrar a passagem do(s) mito(s) para o campo da História. Busca-se compreender o significado e o sentido de tais relatos e obras ao longo do século XIX e sua confluência para o campo religioso brasileiro, em especial o do Nordeste.

As contribuições para o resgate da memória desses fatos são estabelecidas no campo da obra biográfica de Nogueira (1888), O Padre Ibiapina. Ao comparar os textos publicados por Silva $(1913,1915)$, "Padre Ibiapina - traços biográficos encontrados no 
arquivo da Casa de Caridade de Santa Fé, em Arara", no jornal "A Imprensa", aos de Nogueira (1888), "O Padre Ibiapina”, publicado na RIC, Carvalho (2006) chega a assegurar que Nogueira (1888) é o primeiro biógrafo do Padre Ibiapina e aos demais cabe a tarefa de editores. Equivoco que segundo ele, deu-se a partir da publicação de Mariz (1997) ao relacionar José Paulino Duarte da Silva como biógrafo.

Paulino Nogueira foi um dos fundadores da RIC e da Faculdade Livre de Direito do Ceará, foi advogado, desembargador, secretária do Governo da Província da Bahia, vice-presidente e deputado da Província do Ceará pelo partido Conservador. Recebeu o título de cavalheiro da Ordem de Cristo. Ele nasceu em 27 de fevereiro de 1842, falecendo em 15 de julho de 1908 (Nogueira, 1960).

Sua obra literária pode ser considerada um marco iniciático e fundante para a consolidação do mito Ibiapina. Mito aqui entendido como um "sistema dinâmico de símbolos, arquétipos e schèmes' [...] é o remate de todo o processo da imaginação, liberando energia biológica e psíquica para os indivíduos e as sociedades resolverem seus impasses existenciais. [...] ensinando através da repetição, uma proposta de organização do mundo e da sociedade" (Carmona, 2015, p. 91).

Numa linguagem cristianizada diria-se que Paulino Nogueira foi o responsável pela propagação das práticas e valores vividos e disseminados pelo missionário cristão para seus seguidores nos séculos seguintes aos da publicação de sua obra. Fato é que após a publicação da obra $O$ Padre Ibiapina, na RIC em 1888 por ocasião do 5o aniversário de falecimento do padre, seguiu-se inúmeras publicações e relatos que corroboraram para uma vasta bibliografia sobre o referido assunto. Visão esta já defendida por Carvalho (2008).

[...] Às 2 horas da madrughada de 17, estando como em um extase, e despertando, disse; - Aqui festejam umas pessoas, uma vestida de velbutina branca, outra de côr e outras... Uma testemunha presente, dizendo que elle estava vendo coisas bonitas, elle calou-se, mas depois repondeu-lhe: - Como está você ancioso por saber o que outrem está vendo! As 2 horas da madrugada de 18, perguntando que horas eram, apontou para uma vela branca que estava na mesa e depois para cima, sem dizer palvra; mas passados alguns minutos, perguntando de novo que horas eram, disse; Eu quero abençoar a vocês, e abençôou a todos os presentes [...] As 6 horas d'amanhã elle olhou para certa altura, ficou possuido de uma alegria extrema, e apontou dizendo: - Maria! Ali está Maria! Depois apontou para uma beata presente: Minha filha, você está vendo Maria? Tendo resposta negativa, calou-se, mas depois, enchendo-se de novo de alegria, tornou apontando: Lá está Maria! Minha filha, olhe! Não vejo meu pae! Quando foi 2 horas da tarde rendeu a alma ao Creador! Nessa ocasião ouvio-se um trovão, viram-se alguns relampagos e cahio uma chuvinha! It finils. Contava 77 annos de idade e 30 de vida apostolica (Nogueira, 1888, p. 219).

Para compreender a importância deste recorte é indispensável relacioná-lo com o todo da obra. Trata-se de um relato feito a máquina de datilografia com o intuito evidente de guardar a memória e os feitos do Padre Ibiapina. Por diversas vezes, noutros relatos, fica claro essa intenção, mesmo que contrariando as ordens do padre que temia sofrer interrupções ou intervenção nas suas missões e obras de caridade.

Aqui vale o resgate do episódio da Revolução de 1817 e 1824, quando seu pai e irmão foram mortos acusados de participação nas revoltas contra o império e na Confederação do Equador.

Feito essas observações, passemos a análise comentada do fragmento textual. 
Tabela 1. Análise do fragmento textual do relato da morte do Padre Ibiapina.

\begin{tabular}{|c|c|c|}
\hline Classificação & Enunciado & Recorte textual \\
\hline Mito & "bem-nascido" & $\begin{array}{l}\text { Contava } 77 \text { annos de idade e } 30 \text { de vida apostolica } \\
\text { Quando foi } 2 \text { horas da tarde rendeu a alma ao Creador! }\end{array}$ \\
\hline Rito & abençoar & $\begin{array}{l}\text { Eu quero abençoar a vocês, e abençôou a todos os } \\
\text { presentes / }\end{array}$ \\
\hline Divindade & Maria, mãe de Jesus & $\begin{array}{l}\text { enchendo-se de novo de alegria, tornou apontando: Lá } \\
\text { está Maria! Minha filha, olhe }\end{array}$ \\
\hline Objeto & Vela & apontou para uma vela branca \\
\hline \multirow{3}{*}{ Tempo } & \multirow{3}{*}{$6 \mathrm{~h}$ da manhã } & $\begin{array}{l}\text { As } 2 \text { horas da madrughada dia } 17 / \\
\text { As } 2 \text { horas da madrughada de } 18 /\end{array}$ \\
\hline & & $\begin{array}{l}\text { As } 6 \text { horas d'amanhã elle olhou para certa altura, ficou } \\
\text { possuido de uma alegria extrema, }\end{array}$ \\
\hline & & Quando foi 2 horas da tarde rendeu a alma ao Creador!/ \\
\hline Subjetividade & pessoas festejando & $\begin{array}{l}\text { Aqui festejam umas pessoas, uma vestida de velbutina } \\
\text { branca, outra de côr e outras... }\end{array}$ \\
\hline Epifania & $\begin{array}{l}\text { trovão, relâmpagos, } \\
\text { chuvinha }\end{array}$ & $\begin{array}{l}\text { Nessa ocasião ouvio-se um trovão, viram-se alguns } \\
\text { relampagos e cahio uma chuvinha! }\end{array}$ \\
\hline
\end{tabular}

No início do texto em sua íntegra, Nogueira (1888) faz uma exaltação ao caráter, a humildade, ao reconhecimento póstumo àquele que fora "predestinado" a vida missionária. $\mathrm{O}$ autor faz uso de quatro longas páginas poéticas para justificar tamanho reconhecimento público.

Aos ditames de Eliade (2010), pode-se supor que o caminho traçado por José Antônio de Maria Ibiapina até a ordenação foi uma dessacralização em vista de uma pertença profana percebida em sua dificuldade para reencontrar as dimensões do homem religioso e sua própria maneira de viver no mundo. Foi preciso vivenciar uma experiência primária que ele a interpretou como sendo uma teofania sagrada - os três anos de deserto no sítio em Olinda, a conversa com o amigo Américo Militão de Freitas tido como interlocutor da ordenação sacerdotal junto a Dom Perdigão (Nogueira, 1888, p. 194-202).

Ao fim do texto de Nogueira (1888, p. 219) fica mais evidente a ênfase dada aos aspectos heróicos e mitológicos da vida e da missão desse missionário do nordeste. E para não se ter dúvidas de sua dimensão sagrada, o autor termina seu escrito com as seguintes palavras: "Quando foi 2 horas da tarde rendeu a alma ao Creador. Nessa occasião ouvio-se um trovão, viram-se alguns relampagos e cahio uma chuvinha [...]. Contava 77 annos de idade e 30 de vida apostolica". É através da produção e promoção de relatos dessa natureza que se fomenta a construção do mito Ibiapina, e que se estabelece um culto perene em torno das obras e vida do missionário.

Antes dessas palavras Nogueira relata que Ibiapina teria visto a Mãe de Deus e demonstrou isso às beatas que estavam ao seu lado. Depois volta a fazer analogias com personagens da religiosidade cristã como Paulo de Tarso e Francisco das Chagas. Esse conjunto de analogias e descrição de visões reforçam os aspectos de um homem religioso que re-atualiza a cosmogonia ao dominar novos mundos, a regenerar o humano e sacralizar o modus vivendus, ou seja, sacraliza a dimensão existencial. E assim, ao narrar o que estava vendo, Padre Ibiapina estava demonstrando o seu (re)encontro com os "deuses" tal qual nos primórdios - in illo tempore. Segundo Luna (2012) esta também é uma forma de manifestação múltiplas no escopo da teogonia. Por vezes ele é apresentado como um aedo - aquele que entoa no seu leito de morte as fórmulas do bem viver para 
bem morrer; noutros trechos ele é entendido como a própria mensagem - o mito vivo, enviado pela própria divindade ao povo nordestino. É um revestisse de autoridade.

Se foi realidade ou não, o que o Padre Ibiapina descrevera, o que deve ser considerado é que com isso ele revelou uma epifania, um pensamento indireto da realidade e até mesmo uma presença figurada da transcendência que estava presente no relato daquela experiência religiosa. E assim assegurava aos presentes um mistério pessoal, uma comunicação direta com o indizível e irrepresentável representado simbolicamente na transfiguração da mãe de Jesus (Maria). Levando as beatas e devotos da missão a apreender a realidade restauradora por meio da consciência humana por vias perceptíveis. Função específica da imaginação simbólica, segundo Durand (2000).

Nesse caso, ao verbalizar o que estava visualizando substitui os signos convencionais e abstratos incapazes de serem revelados, àquele momento, de forma que se pretendia claramente informar em aspectos humanos. A este grupo específico cabe a primazia do testemunho $a b$ origine, não apenas recordam a história, mas a vivenciam. Para Eliade (2010), "todos esses sistemas se propõem a encontrar o sentido e a direção da História universal". Esse tipo de historiografia se faz útil por conservar a memória das façanhas, os nomes e personagens excepcionais e suas transmigrações. Para os gregos a memória histórica é tão importante quanto a das cosmogonias, teogonias e genealogias. Ambas superam o esquecimento e garantem que a sociedade se firme a partir das experiências de outros.

A epifania aqui descrita tem a função de ratificar a missão, as palavras e ações do missionário. Os raios, trovões e chuvas foi um fenômeno perceptível a todos da região do entorno da cidade de Arara. Esta alteração no tempo e no espaço cronológico apontam para sua qualificação como homo religiosus e assim ele é revestido, outra vez, de autoridade para que suas beatas, beatos, devotos e desconhecidos seguissem com sua obra de caridade. Eliade define que é nesse ambiente que se estabelece a realidade e o sentido de mundo para o homem arcaico.

Na realidade, o ritual pelo qual o homem constrói um espaço sagrado é eficiente à medida que ele reproduz a obra dos deuses. A fim de compreendermos melhor a necessidade de construir ritualmente o espaço sagrado, é preciso insistir um pouco na concepção tradicional do "mundo": então logo nos daremos conta de que o "mundo" todo é, para o homem religioso, um "mundo sagrado". [...] Ora, a existência humana só é possível graças a essa comunicação permanente com o Céu. [...] Não se pode viver sem uma "abertura" para o transcendente; em outras palavras, não se pode viver no "Caos" (Eliade, 1972, p. 21-23).

Nas páginas que antecedem o relato final, é ressaltado o empenho da família em garantir bons meios para que o filho desenvolvesse suas habilidades e potenciais. Pormenorizadamente descreve todo seu trajeto de vida e morte.

Sua organização era fraca, por isso os collegas chamavan-no Pereirinha em contraposição a outros mais corpulentos e robustos. Em princípios de 1823 Francisco Miguel poz-se de viagem para a capital, com toda a família, menos a idolatrada esposa, que havia falecido victima de um aborto (Nogueira, 1888, p. 164).

Os recortes acima podem demonstrar como Paulino Nogueira contribuiu para uma construção imagética e mítica do Padre Ibiapina. Os relatos podem ser entendidos como uma analogia ao Sermão da Montanha, descrito no evangelho de Mateus, capitulo 5, versículos de 1 a 16. Também conhecido como as bem-aventuranças. Em nota de rodapé da edição Tradução Ecumênica da Bíblia (TEB, 1994), os editores afirmam que esse texto das bem-aventuranças é uma pré catequese e que antecede o anúncio do reino sagrado. E

Rev. Bras. Gest. Amb. Sustent., 2020, vol. 7, n. 17, p. 1701-1709. 
que as felicitações se destinam aos que se colocam ao serviço do anúncio desse mesmo reino para as pessoas próximas. 0 mesmo ocorre quando o biógrafo resolve destacar 0 apelido - Pereirinha. É uma forma a ser utilizada para demonstrar que os humildes foram exaltados.

E Jesus, vendo a multidão, subiu a um monte, e, assentando-se, aproximaram-se dele os seus discípulos; E, abrindo a sua boca, os ensinava, dizendo: Bemaventurados os pobres de espírito, porque deles é o reino dos céus; Bemaventurados os que choram, porque eles serão consolados; Bem-aventurados os mansos, porque eles herdarão a terra; Bem-aventurados os que têm fome e sede de justiça, porque eles serão fartos; Bem-aventurados os misericordiosos, porque eles alcançarão misericórdia; Bem-aventurados os limpos de coração, porque eles verão a Deus; Bem-aventurados os pacificadores, porque eles serão chamados filhos de Deus; Bem-aventurados os que sofrem perseguição por causa da justiça, porque deles é o reino dos céus; Bem-aventurados sois vós, quando vos injuriarem e perseguirem e, mentindo, disserem todo o mal contra vós por minha causa. Exultai e alegrai-vos, porque é grande o vosso galardão nos céus; [...] Vós sois a luz do mundo; não se pode esconder uma cidade edificada sobre um monte; Nem se acende a candeia e se coloca debaixo do alqueire, mas no velador, e dá luz a todos que estão na casa. Assim resplandeça a vossa luz diante dos homens, para que vejam as vossas boas obras e glorifiquem a vosso Pai, que está nos céus (TEB, 1994, Mateus, 5:12). (Grifos dos autores).

Ao fazer a descrição da vida, do advogado, do juiz, do deputado e missionário, Paulino está evidenciando, mesmo sem saber, o perfil mitológico desse sacerdote. E ao cabo, suscita em seus seguidores uma pertença e uma identificação na busca pelo sagrado. 0 resgate da condição anterior a "queda" adâmica. Oferecendo ao povo das missões um precedente exemplar para todas as ações e situações que possam promover uma experiência visível da eternidade.

Nesse aspecto o povo das missões assumia para si os mesmos ideais e partilhavam das mesmas circunstâncias sociais ao ponto de encontrar nessa devoção um ato capaz de identificá-los visivelmente no meio de uma sociedade tão dispersa. "[...] com o fim de provar religiosa abnegação, não se lhe davam mais a conservar seus nomes pelos quais eram conhecidos [...], colocavam adiante de seu primeiro nome o de Maria [...]" (Mariz, 1997, p. 70).

Sua contribuição para a bibliografia e para os devotos do Padre Ibiapina se dá nesse contexto de assegurar e garantir que seus ditos, escritos e feitos permaneçam lembrados e rememorados no imaginário dos devotos e amigos do missionário.

As obras e ações do Padre Ibiapina são parte do arcabouço etnográfico usado por boa parte de seus editores e que revelam uma intencionalidade direta, nas maiorias das obras, de reconhecimento da formação e fomento de uma tradição religiosa em torno de sua personalidade. No nosso caso, especificamente das Ciências das Religiões (CR), percebe-se suas obras e falas como coluna mitológica para a manutenção e consolidação do cristianismo à sua época. Conforme Luna (2012), a construção mítica se faz por um conjunto de minimitos que ascende para o mito maior, ou seja, o mito do "bem-nascido".

Essa construção linguística e visual de cunho tanto coletivo quanto individual, é típico das nuanças encontradas ao trabalhar com o cristianismo por se tratar de uma formação repleta de elementos mitológicos e históricos. Seus símbolos, ritos, figuras e rituais se coadunam milenarmente as culturas locais, ressignificando e aculturando-se para manter-se viva.

Os relatos das missões, as atas das Sessões da Assembleia, as Cartas às Casas de Caridades, as Cartas aos Regentes das Províncias, o Estatuto e Regimento das Casas de Caridade, máximas espirituais, poesias e orações, enquanto construção historiográfica, 
seguem o oportuno elo de resgate dos acontecimentos e abre espaços para suas plausíveis interpretações e interpelações.

Os relatos biográficos da vida e da missão do padre foram produzidos ao longo da segunda metade do século XIX quando este começou a ser percebido como uma pessoa que destoava do seu tempo. As obras editorias são produzidas e publicadas até os dias atuais. Nesse contexto, faz-se necessário um destaque específico à obra de Carvalho (2008) A Missão Ibiapina.

Carvalho (2008) produz uma obra atualizada e corrigida, apresenta e esclarece alguns equívocos produzidos no campo editorial. Ele faz uma compilação pormenorizada de várias fontes comparando-as com o texto biográfico de Paulino Nogueira, 1888. 0 primeiro capítulo é formatado com o texto publicado por Hoornaert (2006) que segue corrigido ou complementado pelo de Silva $(1913,1915)$. Em seguida, Carvalho (2008), faz destaque apenas aos textos publicados por Paulino Duarte e por fim faz referência aos textos tidos como escritos pelo próprio Ibiapina, que se constitui em quatro textos temáticos e um texto do editor em forma de síntese historiográfica e cronológica dos eventos e publicações que constituem o registro para a memória do sacerdote. Esta intencionalidade dos editores e biógrafo fica evidente na citação do próprio Carvalho (2008, p. 22 e 196).

Na obra Mito e Significado, Lévi-Strauss suscita um questionamento que requer uma resposta direta - que significado tem estas histórias recolhidas? Ao analisar a obra de Carvalho (2008) fica evidente o significado de tais aglutinações, compilações e enredos. Primeiro o de organizar, cronologicamente, todos os eventos em forma de texto para facilitar a compreensão do leitor e assegurar o lugar do mito no tempo e na história. Depois, inconscientemente, Carvalho produz uma obra sui generis que fixa no campo historiográfico a biografia do Padre Ibiapina, ao passo que produz uma obra editorial religiosa, devocional e historiográfica. Nossa ressalva enquadra-se no pouco cuidado do autor em separar o sentimento devocional do perfil de editor. Mas aceitável por se entender que o objetivo principal, para Carvalho, era o de promover uma obra promocional da tradição Ibiapina e sua relevância para o catolicismo paraibano.

Nesse ínterim, ele relaciona as diversas produções editorias com a biográfica, apresentando-nos os pontos de encontros, os análogos e as divergências entre tais obras. Identifica as características comuns do missionário e sua relação com o ethos religioso cristão católico de sua época e como este torna-se uma figura notória no campo religioso, político e social. Elementos constitutivos dos destaques apontados pelos editores do missionário.

A análise mítica recai ao pesquisador das CRs. Este por sua vez desenvolve uma produção aberta e intermediária entre a História e a construção mitológica. Esta última, de caráter estático, ou seja, se repete em vários acontecimentos mesmo que manifestado nos mais diversificados ambientes. Já a História se configura como um sistema aberto.

Desta forma, encontra-se na obra de Carvalho (2008) um marco de consolidação da passagem do mito para a história. Trata-se de uma obra com um conjunto de relatos (palavras, signos, imagens, paisagens) com a mesma função desempenhada pelo mito, que é a de assegurar que no futuro tais contos sejam lembrados, rememorados e festejados como no passado. E assim cumpre sua função de ensinar ao homo religiosus a conviver com a tradição arcaica. Ele faz uso do livro "para explicar a origem de uma ordem social que era a ordem social daquele período histórico" (Lévi-Strauss, 2007). E assim considera-se um elo entre história e mitologia, ou seja, "[...] a ciência explica a sua própria validade, em certa medida, é válido no pensamento mitológico" (Lévi-Strauss, 2007, p. 25).

Rev. Bras. Gest. Amb. Sustent., 2020, vol. 7, n. 17, p. 1701-1709. 


\section{Considerações finais}

Nesse contexto da vida, das obras, da morte, do resgate da memória do Padre Ibiapina se encontra a assertiva para este trabalho. Assim como os heróis gregos, que permanecem vivos na memória e na tradição dos povos de hoje, Ibiapina permanece na memória devido às suas obras e feitos. Transpassando o rio do esquecimento sem perderse na memória e tendo seus feitos como "verdade" divina. Sua geração foi testemunha das manifestações cosmogônicas passando a compreendê-lo enquanto étymon. Sua verdade foi testemunhada por várias pessoas, seus atos foram ratificados, seu biógrafo e editores tomaram a mão todos os meios linguísticos possíveis a fim de garantir sua Verdade como mensageiro e mito da revelação divina. Uma revelação, uma aletheia, que não requer fundamentos racionais para compreendê-los, basta vivenciar.

No cumprimento do papel de historiador e pesquisador, é preciso um destaque nessa construção biográfica e editorial. Todas essas construções textuais só se processaram a partir dos relatos dos beatos e beatas que podem ser configurados como guardiãs e guardiões desse registro no campo do patrimônio historiográfico, a saber, o Antônio Modesto de Maria Ibiapina que viveu até o ano de 1927 com beato e autor do relato do fim da vida do Padre Ibiapina. Para o tempo presente o destaque cabe ao Padre José Floren, ex-reitor do Santuário que realiza uma busca constante para resgatar documentos que ainda não foram publicizados e divulgados, embora essa não seja sua função principal. Os demais já foram mencionados neste texto.

Por fim, trata-se de uma forma relativa do mito do "bem-nascido", uma analogia que resgata o universo dos bem-aventurados e promove o entendimento de uma mensagem divina.

Dessa forma, nosso aporte teórico encontra amparo no campo etnográfico. Numa etnografia aberta, comunicativa e que dialoga com as ciências das religiões. Na análise comparativa buscou compreender tal passagem do mito para a história observando as complexidades da temática sem estabelecer conceitos prévios.

\section{Conflito de interesses}

Os autores declaram não haver conflito de interesses.

\section{Referências}

Carmona, R. M. Ressignificando a finitude do homem na identidade devocional de São José da Boa Morte. In: Cavalcanti, C. A.; Cavalcanti, A. P.; Carmona, R. M. (Orgs.). o que se vê nas religiões? imaginário, história e diversidade (Textos do Videlicet). João Pessoa: Editora Universitária/UFPB, 2015. p. 87-95.

Carvalho, E. T. A Missão Ibiapina. Passo Fundo: Berthier, 2008.

Durand, G. A imaginação simbólica: perspectivas do homem. Lisboa: Edições 70, 2000.

Eliade, M. Mito e realidade. São Paulo: Perspectiva, 1972.

Eliade, M. 0 sagrado e o profano. 3. ed. São Paulo: Martins Fontes, 2010.

Lévi-Straus, C. Mito e significado. Lisboa: Edições 70, 2007.

Luna, S. Drama social, tragédia moderna: ensaios em teoria e crítica. João Pessoa: UFPB, 2012.

Mariz, C. Ibiapina, um apóstolo do Nordeste. Fac-simile da edição de 1942. 3. ed. João Pessoa: Editora Universitária/UFPB, 1997. 
Nogueira, P. O Padre Ibiapina. Revista do Instituto do Ceará, Anno II, p. 157-220, 1888.

Nogueira, P. Apontamentos autobiográficos do Bel. Paulino Nogueira Borges da Fonseca e de seus parentes, pais, irmãos e tios. Revista do Instituto do Ceará, Anno LXXIV, p. 270-285, 1960.

Silva, J. P. D. O Padre Ibiapina. Revista do Instituto do Ceará, Anno XXVII, p. 189-202, 1913.

Silva, J. P. D. O Padre Ibiapina: notas sobre a sua vida, extrahidas do archivo da Casa de Caridade de Santa Fé e dadas a lume pelo autor. Revista do Instituto do Ceará, Anno XXIX, p. 90-142, 1915.

TEB - Tradução Ecumênica da Bíblia. Bíblia sagrada. São Paulo: Loyola, 1994. 